\title{
SCHOOLING AND THE PRODUCTION OF LOCAL COMMUNITIES IN MID-NINETEENTH-CENTURY AUSTRALIA
}

\author{
Malcolm Vick
}

This paper explores some ways in which the provision and management of schools in mid-nineteenth-century Australia shaped the local communities of which they were a part. It argues that the existence of schools, especially public schools in purpose-built accommodation, played an important role in shaping local society, geographically, culturally, and politically, and in positioning local society in relation to the colonial state.

For much of the historiography of Australian education, the local level is either irrelevant and ignored, or unexplored but dismissed as unimportant if indeed not actually an impediment to the development of modern schooling. ${ }^{1}$ However, some studies do look more closely at this aspect of mid-nineteenthcentury schooling. Several studies have explored aspects of schooling, especially the work of teachers, in local contexts. ${ }^{2}$ Others have considered the place of local educational activity in the development of centralized systems. Ely and Pawsey have looked at ways in which central education bureaus sought to mobilize local activity as a tactical move in political struggles over the shape of the state education systems. ${ }^{3}$ Ely, Grundy, Payne, and others have explored the place of localism in the strategies the central boards and their political supporters generated for developing systems. ${ }^{4}$ Hirst argued that local action was fundamental to

1. M.J. Vick, 'Representing Localism: Society, the State and the Historians of MidNineteenth-Century Australian Education,' paper presented to ANZHES Conference, Adelaide, 1986.

2. See, especially, the studies in R.J.W. Selleck \& M. Sullivan, eds., Not So Eminent Victorians (Melbourne, 1984), and those by Theobald, Selleck, and Sherington in Family, School and State in Australian History, ed. M. Theobald and R.J.W. Selleck (Sydney, 1990).

3. M.J. Ely, 'Politics, Education and Administrative Centralization: National Education in New South Wales, 1856-1866' in Melbourne Studies in Education 1975, ed.

S. Murray-Smith (Melbourne, 1975); M. Pawsey, 'Backroom Politics and Educational Reform: The National Board and Victoria's Common Schools Act,' History of Education Review 12, 2 (1983).

4. M.J. Ely, 'The Management of Schools in New South Wales, 1848-1880: Local Initiative Suppressed?' Journal of Educational Administration 9, 1 (1979); D. Grundy, 'The Political Economy of the Denominational System of Schools in 
mid-century strategies for developing state schooling and that it was effective in providing schools through most of the colony. ${ }^{5}$ I have elsewhere looked at the character, extent, and bases of local educational activity, and the role of such activity in virtually forcing the central boards to marginalize localism. ${ }^{6}$ And Smith, while sharing the traditional view that localism was essentially irrelevant to the development of state education, argues that position on the basis of a carefully theorized account of the premises of the 'liberal classroom' which formed the centrepiece of state educational strategy.

There are important and interesting parallels between these Australian studies and a body of work in and on North America, Britain, and continental Europe. The work of Cremin, Frith, Gardner, Gidney, Johnston, Laqueur, and Vincent, for instance, demonstrates the importance of education in popular culture, and the proliferation and diversity of forms of both informal education and formal schooling. ${ }^{8}$ This work together with that of Marsden, Madoc-Jones, Maynes, and Stephens has indicated a range of ways in which local conditions shaped the

Victoria,' in Melbourne Studies in Education 1981, ed. R.J.W. Selleck (Melbourne, 1981); E.J. Payne, 'The Management of Schools in New South Wales (1848-1866): Local Initiative Suppressed,' Journal of Educational Administration 6, 1 (1968). See also S.G. Jackel, The Decline of Local Influence in the Administration of Elementary Education in Victoria, 1862-1884 (M.Ed. Minor Thesis, University of Melbourne, 1980); and H.J. Lawry, “"A Perpetual Struggle for Power...”: Local Control of Education in Nineteenth Century Victoria-Origins of the Concept and Causes for its Abandonment' (Ph.D. diss., Monash University, 1986).

5. J.B. Hirst, Adelaide and the Country (Melbourne, 1973).

6. M.J. Vick, 'Class, Gender and Administration: The 1861 Education Act in South Australia,' History of Education Review 17, 1 (1988); M.J. Vick, 'School, Community, the State and the Provision of Schools in Mid-Nineteenth Century South Australia,' Australian Historical Studies 25, 98 (1992); M.J. Vick, "“Their Paramount Duty": Parents and Schooling in the Mid-Nineteenth Century,' in Family, School and State, ed. Theobald and Selleck.

7. B. Smith, 'William Wilkins' Saddlo-bags: State Education and Local Control,' in Family, School and State, ed. Theobald and Selleck.

8. L. Cremin, American Education: The Colonial Experience (New York, 1970); S. Frith, 'Socialization and Rational Schooling: Elementary Education in Leeds Before 1870 ,' in Popular Education and Socialization, ed. P. McCann (London, 1977); P. Gardner, The Lost Elementary Schools of Victorian England (London, 1984); R.D. Gidney, 'Elementary Education in Upper Canada: A Reassessment,' Ontario History 65 (1973); R. Johnson, "'Really Useful Knowledge”: Radical Education and Working-Class Culture, 1790-1848,' in Working Class Culture, ed. J. Clark, C. Critcher and R. Johnson (London, 1979); T. Laqueur, 'The Cultural Origins of Popular Literacy in England, 1500-1850,' Oxford Review of Education 2, 3 (1976); D. Vincent, Bread, Knowledge and Freedom: A Study of Nineteenth Century Working-class Autobiography (London, 1981). 
provision and use of schools to produce quite uneven patterns of education. ${ }^{9} \mathrm{Katz}$ pointed out the existence of 'democratic localist' possibilities for school provision and management. ${ }^{10}$ Gidney, Lawr, and Millar have shown ways in which local activity both shaped the effects of state support for education at the local level and forced the development of decision-making criteria and procedures of the state bureaus. ${ }^{11}$ Finally, Curtis has shown the diversity of local educational activity, the ways in which such activity shaped both local provision and the development of the machinery of state, and the ways in which the central education bureaus sought to actively construct forms of procedure in the local conduct of public (educational) business and in doing so, to reconstruct local society. Such parallels are, of course, hardly surprising. They reflect both the important similarities in the general character of western societies argued by Davey, Miller, and Curtis, ${ }^{12}$ and the differences in detail between Australian and other European, and European colonial, societies and education.

One merit of such studies is that their focus on the relation between educational developments and the specificity of local conditions and circumstances helps us understand the school-society-state relationship in political, as well as structural terms, and directs us to the ways in which structures which we may easily take as basic were apprehended and constituted in daily practice politically. However, most of these studies focus on the ways in which social context shapes schooling. Curtis is an exception, in that his work also examines the ways in which the provision of schooling shapes local society. He does this in two ways. First, he examines in detail the local politics most immediately and directly related to school. Second, he offers a highly abstract reading of local education politics

9. B. Madoc-Jones, 'Patterns of Attendance and Their Social Significance: Mitcham National School 1830-1839,' and W.E. Marsden, 'Social Environment, School Attendance and Educational Achievement in a Merseyside Town,' in Popular Education and Socialization, ed. P. McCann; M.J. Maynes, Schooling for the People: Comparative Local Studies of Schooling History in France and Germany (Albany, N.Y., 1985); W.B. Stephens, Education, Literacy and Society, 1830-1870: The Geography of Diversity in Provincial England (Manchester, 1986).

10. M.B. Katz, The Illusion of Educational Change in America (New York, 1971).

11. R.D. Gidney and D.A. Lawr, 'Bureaucracy vs Community? The Origins of Bureaucratic Procedure in the Upper Canadian School System,' Journal of Social History 13, 3 (1980); R.D. Gidney and W.P.J. Millar, 'From Voluntarism to State Schooling: The Creation of the Public School System in Ontario,' Canadian Historical Review 66, 4 (1985).

12. B. Curtis, 'Capitalist Development and Educational Reform,' Theory and Society 13, 3 (1984); I.E. Davey, 'Capitalism, Patriarchy and the Origins of Mass Schooling,' History of Education Review 16, 2 (1987); P. Miller and I. Davey, 'Family Formation, Schooling and the Patriarchal State,' in Family, School and State, ed. Theobald and Selleck. 
in the construction of a public domain of the state. This paper, in contrast, looks at the more diffuse effects of schooling in local social life, as well as at the (changing) position of the local level in the constitution of the state.

Before looking at the way in which the provision of schools shaped local society, it is necessary to note that most settlements had at least one school; many, even quite small, villages had more than one, while larger towns, the capital cities, and their suburbs had considerable numbers, often located quite close to each other. These schools varied widely in the character of their accommodation, curriculum and pedagogy, and clientele. The evidence for this lies in the occasional census and other official statistical returns for each colony, the inspectors' reports and other documents associated with the establishment of new state-supported schools, correspondence generated when individual schools were beset by crisis, and newspaper advertisements and articles.

\section{Local Development}

To start with, the provision of schools helped determine the shape-the spatial form-of local communities. Where special-purpose school buildings were provided, their location had an important effect on the geography of local development. They might be central to the existing settlement, adjacent to local businesses, pub, church, police station, and so on, or separate, either outside the boundaries of the settlement, or away from its centre(s), apart from other buildings, or loosely surrounded by domestic dwellings. Such developments effectively consolidated an existing centre or, alternatively, dispersed it, perhaps even providing the core for a new centre of activity. Where settlements existed close to each other, the decision to erect a school building at some point between them could well foster a pattern of growth in which the two settlements became more integrated. Alternatively, the erection of school buildings in both settlements enabled their development to continue independently, while a school in one but not the other could lead to the latter becoming an appendage, or satellite, of the other.

Let me illustrate these points. In the Woodside-Balhannah district in the Adelaide hills there were many small settlements scattered within easy reach of each other. The decision to erect a public school building at Oakbank, barely established at the time as a private village, was crucial to the development of that settlement, at least in the view of local settlers in the area. Subsequently, settlements such as Oakbank, Balhannah, and Woodside (each of which soon established its own school building), grew into more substantial towns, while others, such as Inverbrackie, which was unable to secure a school, never did. ${ }^{13}$

13. South Australian Public Record Office [SAPRO], GRG 18/113/27, 18/113/30. 
At Kyneton in Victoria, the original public school building was located midway between the established town centre and the looser village of East Kyneton. Over the following years, the area between the two gradually filled until the school was in fact surrounded by the town and the two merged into a single town. ${ }^{14}$ In contrast, in the One Tree Hill area northeast of Adelaide, the neighbouring settlements of Uley Bury and Precolumb each erected a school building; despite being only a mile or so apart, they retained their separate identities and grew apart rather than together. ${ }^{15}$

In part, schools helped shape local communities spatially because they were a valued resource, a means by which parents could educate their children. Consequently, the availability of a school was one of the things to be considered when deciding where to settle. This might reasonably be inferred from advertisements which mentioned the proximity of, or provision made for, a school (alongside post office, police station, church, and so on), as well as claims such as those made in the Oakbank case mentioned above. There is also some more direct evidence, in the form of parents stating that they had moved to a place specifically because they would be within reach of a school. Again, this must have been a more important consideration in rural areas, given the density of school provision in the towns and cities. Perhaps it was also more important for those who saw themselves as putting down roots in a locality rather than passing through it. However, they might also reasonably anticipate the establishment of a school whereas those with more limited tenure were more reliant on what was already provided. What we are dealing with here is a set of considerations involving, on the one hand, the reality of existing amenities as against the possibility of future amenities, and on the other, parental concerns to secure schooling for their children as against well-established practices of providing schooling in intermittent fashion over the years of childhood. However such considerations might have been resolved in individual cases, the fact remains that for parents access to a school must have counted in favour of a place to live.

Where schools were held in makeshift accommodation, as many were, they had little if any impact on the spatial development of settlements. There was no investment in infrastructure to be protected, no especial reason associated with the school itself why other developments should be undertaken in that part of the settlement (although the same factors which led to a school being established there might serve independently to attract other developments). And the school could be easily relocated in response to any number of contingencies, including those which might lead to a loss of pupils. Rather than shaping local geography, then, schools in such accommodation followed the direction of local development determined elsewhere.

14. Victorian Public Record Office Series [VPRS], 23.

15. SAPRO, GRG 18/113/20, 21. 
Clearly, this line of argument about the significance of school buildings to the geography of local development is not without its problems. To start with, it has limited application. It does not seem to apply to well-established centres of population, notably the capital cities, their well-developed suburbs, and major country towns. Rather, it appears relevant to newer, or smaller, settlements, especially in the country districts but also in those suburban districts which continued to be relatively open and sparsely filled until well after mid-century. Second, it assumes a counterfactual position: without a school at one particular spot, development might have taken a different shape. Third, and relatedly, it suggests a causal relationship which it cannot demonstrate and which, in any case, would need to be qualified in each instance to allow for the interaction of other factors shaping development. (In the Uley-Precolumb example above, for instance, the fact that there was a deep gully between the two was crucial to the pattern of development.) And fourth, it is to a large extent a hypothetical argument, in that it rests on fragments of evidence and a sense of possibilities and probabilities rather than the systematic analysis of a large series of close-grained individual case studies. Nevertheless, it indicates one of the ways in which schools, through the buildings they occupied, shaped local communities, an issue to be further explored and its complexities teased out.

Schools also helped shape local development by virtue of their contribution to the local economy. Schools which received support from the central educational agencies drew money into local economies. School building subsidies were a windfall to local contractors and tradesmen [sic], boosting their profits, allowing them to employ labour, and putting money into circulation in the local economy. ${ }^{16}$ They might even draw such money in with no financial outlay locally; in many cases settlers found the materials in the immediate vicinity, and donated their labour in slack periods, thus in effect producing a local resource at no direct cost to themselves.

Finally, schools contributed to the development of local social infrastructure. In smaller settlements, local resources were insufficient to maintain such individuals or institutions as a post office/postmaster or mistress, or a clergyman or priest. The income derived from school fees, even if supplemented by the state education board, might be-and often was-little more than a pittance, but where more than one such position was held by a single person, the combined incomes might be sufficient to maintain each institution. School buildings often provided accommodation for church services, public meetings, and entertainments, state financial contributions to them thus subsidizing far more than the school alone. And the teachers themselves constituted a valued social resource within the community, serving as letter-writers, newspaper correspondents, Sunday school teachers, and so on.

16. Hirst, Adelaide and the Country, 144-52. 


\section{Local Culture}

\section{The Symbolic Ordering of Social Life}

Schools also helped constitute the character of local culture. At a highly general level, their physical and institutional form provided markers of the cultural/conceptual structuring of daily life. A school which shared its premises with a local church, or was held in the local chapel, marked the close relationship between not simply religion and education, but church and schooling. Insofar as such schools received state support they further announced a particular relationship between church and state. Schools which were held in state-subsidized special-purpose buildings which were unavailable specifically for religious purposes, such as the National schools, proclaimed a quite contrary relation between the two, one of radical separation. Moreover, the fact that such school buildings were also unavailable for political meetings, but were used for public lectures, entertainments, bazaars, and other such 'non-religious' and 'non-political' activities also symbolically defined the state school (and with it, arguably, both the state, and education) as standing over and above social division, as what Gregory called the symbol of common citizenship ${ }^{17}$-not a vague, empty symbol, but one which constituted what it represented, which embodied and produced that common citizenship of which it spoke.

Schools also played an important part in the symbolic construction of social life around the division between the public and the private or domestic spheres. A school in a private dwelling marked the continuity of the public and private domains, and identified education with the domestic sphere. Indeed, as Theobald has argued, in the case of many of the private schools for young ladies, this continuity between school and domestic life was crucial to the schools' educative work. $^{18}$ In contrast, a school in a special-purpose building, such as those which were subsidized by the state education boards, marked the separation of the two.

In many cases, the large imposing stone or brick buildings and stout fences or walls which surrounded them announced only too clearly the distance between school and community and the restricted conditions under which members of the community could enter them. However, the relationship was not always clear or unambiguous. Many schools occupied special-purpose buildings which included a teacher's residence. Such schools combined both public and private/domestic, and, as Theobald (again) has shown, there was often considerable traffic between

17. Cited in A.G. Austin, Australian Education 1788-1900: Church, State and Public Education in Colonial Australia, 3rd ed. (Melbourne, 1972), 112.

18. M.R. Theobald, "'Mere Accomplishments"? Melbourne's Early Ladies' Schools Reconsidered,' History of Education Review 13, 2 (1984). 
the two, marking not only their separation but the ambiguities and continuities in the relationships between them.

Ambiguities and continuities can also be read in the architectural style of such buildings. Many, including those which were formally 'secular' schools, drew visibly on distinctive elements of church architecture, while others closely resembled domestic dwellings. Increasingly, however, special-purpose school buildings developed a range of styles of their own, quite distinct from domestic, religious, and even other public buildings such as police stations, post offices, railway stations. ${ }^{20}$ I suggest that we can read here the shift towards the cultural presence of the school as an independent, autonomous, secular institution firmly located in the public domain, its significance no longer consciously governed by its relations to religion or the family. Where 'older' styles continued to exist, as they did throughout much of the colonies, the 'earlier' associations continued to exist as part of local knowledge of the place of school in the broader institutional framework of social life.

\section{Moral Norms}

Schools also constituted one focus around which a range of moral norms governing social life might be contested. The teacher's position as a public servant-a servant of the local community, like a clergyman and unlike, say, a private economic entrepreneur-and one, moreover, in charge of the (morally vulnerable) young and charged with being their moral exemplar, made his or her activities, whether 'public' or 'private,' important. The contrast with private teachers is significant here. When a private teacher transgressed anyone's moral norms, the appropriate action was to withdraw support from the school; his or her action only became a matter of public concern and investigation if it actually broke the law. Community comment on a private teacher's behaviour might enjoy the status of gossip, no more. The conduct of public teachers' lives (sexual, religious, commercial, and social-their sobriety, their family life, social relations, dress, regularity and reliability of habit, honesty) both in and out of school was subject to legitimate community scrutiny, all brought into public discussion, especially when they might be identified as crossing the boundaries of propriety.

19. M.R. Theobald, 'Women's Teaching Labour: The Family and the State in Nineteenth-Century Victoria,' in Family, School and State, ed. Theobald and Selleck.

20. For generous documentation of the appearance of (mainly public) school buildings see L. Burchell, Victorian Schools. A Study in Colonial Government Architecture 1837-1900 (Melbourne, 1980); J. Burnswood and J. Fletcher, Sydney and the Bush: A Pictorial History of Education in New South Wales (Sydney, 1980). For South Australia, see plans and drawings of proposed school buildings in the series GRG 18/113. 
Take the case of the teacher accused of exposing himself in the local pub at Raglan in Victoria. ${ }^{21}$ He had, it seems, been drinking and joining in (if not leading) the singing of bawdy songs; this was attested by several witnesses including one of his pupils at the local school, and was not seriously disputed. The father of the pupil claimed that he had objected; that the teacher had made a pun on his name, 'Badcock,' and declared that he, in contrast, had a 'good cock' and exposed himself.

The dispute can be seen as part of the construction of local moral norms in two senses. First, while the school inspector's investigation centred on the factuality of the complaint, the hearing of the dispute allowed the constant re/construction of a vocabulary of sexual/social/ moral norms, of the general terms of discussion as well as of fine distinctions and nuances. And second, while the general tenor of the discussion, in my own reading of it, points to the teacher's 'guilt,' his supporters were able to ensure that he was exonerated. (Interestingly, in all this dispute, there was no comment about the presence of the pupil, young master Badcock, in the room at this time.) Local practice, to a large extent, supported norms of behaviour quite different from those which framed the formal conduct of the dispute.

In more general terms, this dispute and its resolution articulated a language (or set of languages) with which to chart the terrain of moral action. It re/defined areas of widespread agreement concerning moral propriety as well as matters of disagreement. Moreover, it nuanced the language of morality to position women and children differently from men. In doing so it endorsed a particular form of masculinity which established the public house as a male domain in which certain forms of public sexuality were permitted which would have been proscribed elsewhere and in which it was permissible for male children to be present where adult men were drinking and engaging in sexual banter. We might notice, too, the role of such an incident in endorsing the induction of young men into this particular form of patriarchal culture and its construction of gender relations and, perhaps, in defining the boundaries between different 'stages' of childhood. The conflict over the legitimacy or otherwise of the teacher's behaviour indicates the presence of multiple, conflicting, values and practices.

\section{The Conduct of Public Business}

The conduct of school business provided both occasion and model for the conduct of public business more generally. In this, the Australian colonies were essentially no different from the Canadian ones where, as Curtis shows, the conduct of local school affairs might be seen as learning the rules and establishing

21. VPRS, $892 / 70$. 
the procedures of democratic political life. Not just any rules and procedures, of course. The formation and running of a local public school involved petitioning, collecting contributions, organizing means of accountability for monies collected, electing representatives to conduct school affairs or, in more general terms, learning the practices of efficient, accountable, representative local government and the rational, democratic resolution of conflict. And, importantly, such things were learned not as formal, abstract 'book' knowledge, but as practical knowledge, naturalized as 'this is how we do things' or, even more powerfully and universally, 'this is how things are done.'

\section{School Knowledge}

Schools, through their curricula, the public demonstrations of children's learning, and private communication of school knowledge to local families both through school texts and children's learning demonstrated at home, as well as through public lectures and discussions, put into circulation the particular corpus of ideas and practices which schools endorsed. Moreover, they instructed parents as well as children concerning the nature, authority, and forms of knowledge: that texts were the authoritative bearers of knowledge, that knowledge was organized into subjects, that some subjects were more important than others, and that different knowledges were appropriate to some classes of individuals and not others. Importantly, while these knowledges were commonly presented as if they were simply 'facts' or 'truths' about the world, they were far more than that. As Donald, in particular, has shown, they offered ways of knowing the self in relation to the world, a range of subject positions to occupy in different (imaginary and practical) contexts. ${ }^{22}$

Schools also taught members of their local communities about the proper purposes and forms of education itself, through the forms of organization they adopted, their curricula and pedagogies, the demands they made of parents to send their children 'regularly' and 'punctually,' and practices such as the setting of homework. In this context, the inspectors' judgements on their practices provided an authoritative statement to the community concerning those aspects of their local school's practice which were 'proper' and those which were not. At times, too, the inspectors offered local managers and parents explicit accounts of the principles and practices of 'good' schooling as a means of teaching them the difference between what they (the parents and managers) considered good education and what actually 'was' good education.

22. J. Donald, "Beacons of the Future": Schooling, Subjection and Subjectification,' in Subjectivity and Social Relations, ed. V. Beechey and J. Donald (Milton Keynes, 1985). 
As with other aspects of the effects of schooling, especially public schooling, in local communities, the results of this 'teaching,' both of formal school knowledge and about education, were contested and uneven. Organizational, curricular, and pedagogical practices differed widely between schools, and even in the case of public schools practice usually differed from the norms articulated by the inspectors. Moreover, parents and others often rejected the lessons the school offered them. Sometimes they explicitly contested the knowledge selection and the procedures for teaching it. At other times, they simply ignored it, continuing to send their children in accordance with their economic and other needs, using, and allowing their children to use, language practices the school described as wrong, and so on. At the same time, it seems likely that the authority of the school was growing, and that the disjunction between school and many popular practices generated tensions and produced a sense of inferiority in many parents and their children.

\section{Local Social Structure and Politics}

Schools were implicated in the re/formation of local social structures and relations in many ways. They can, for instance, be seen as playing a significant part in the construction of a sense of collective local identity. Where a single school reflected a general, unified, local effort, this almost necessarily reflected some existing sense of collective identity. However, the organization of such focused effort must have contributed to the further consolidation of that sense of identity. Certainly there is a considerable body of correspondence from local school organizers to central educational agencies which appears to reflect such a local identity. The representatives of the school committee at one largely German settlement in South Australia, for instance, certainly invoked a strong sense of local solidarity in support of the sort of curriculum they proposed. ${ }^{23}$ Their national and linguistic identity was obviously a key factor underpinning such solidarity. The important thing here, however, is that the formation of a school and the consequent dispute with the state education board over the character of that school provided an occasion to act on, and, in the process, confirm and reaffirm that identity. Moreover, it was articulated not as a German identity, but as a local one. And there are similar cases where neither national identity and language, nor the other obvious unifier, religion, was involved. A newspaper editorial at Ballarat called on the managers of two of the local public schools to maintain their buildings and grounds better because it reflected badly on the reputation of the town as a whole; the town is attributed a collective identity and

23. SAPRO, GRG $18 / 113 / 75$. 
pride. ${ }^{24}$ This should not be surprising; a wide range of issues and incidents arose from time to time over which communities constructed a sense of their own local identity, especially in defining themselves as against others whom they saw as unduly favoured, or as deciding matters they considered of local relevance, for them, and contrary to their own views.

Sometimes, no doubt, the provision of several different schools within the same locality reflected nothing more than personal squabbles between parents and teachers or between different families, idiosyncratic preferences for one style of teaching rather than another, or local geography. Elsewhere, however, it clearly reflected more systematic social division. Most obviously, support for rival or alternative schools was shaped by differences in religion. Indeed, one of the criticisms of the 'dual' systems in New South Wales and Victoria was that they divided the school-age population between rival denominational schools. However, there is plenty of evidence that different schools also enjoyed the support of different social classes. Clearly, the relatively dense populations of the cities, suburbs, and larger towns facilitated such a social differentiation of school, but even quite small places often supported schools for different social groups. In the relatively small country village of McLaren Vale in South Australia, the mansion of the Aldersey sisters housed a boarding school for young ladies, while the gatekeeper's cottage was occupied by a day school for village children. 25

The patterns of provision and support for schools not only reflected existing social divisions, but confirmed and elaborated them. Schools differed, often markedly, from each other, in curricula, pedagogical and organizational style, character, background and education of teachers, and the character of their accommodation. Insofar as the differences between schools corresponded to differences in the social position of those who attended them, the schools elaborated social differences as education and cultural ones, social differences which might be marked by accent and other language practices, different knowledges, even different ways of comporting themselves and relating to others.

They also modified existing social divisions, and made the structural relations constituting local society more complex. They divided otherwise seemingly clearly identifiable, solid groups, into groups with distinct identities. Some German communities, for instance, were divided over strategies for education, some supporting an English-oriented schooling, others a more distinctively German school. ${ }^{26}$ Similarly, some Catholics supported National schools while others strongly preferred an education more thoroughly permeated by Catholic

24. The Star [Ballarat], 24 June 1862.

25. A. Pridmore, The Rich Valley (McLaren Vale, South Australia, 1949), 49-51.

26. J.E. Zweck, 'Church and State Relations as they Affected the Lutheran Church and its Schools in South Australia 1838-1900' (M.Ed. thesis, University of Melbourne, 1971). 
religion. And they might compound these and other divisions (landowners and tenants, townspeople and farmers) with alternative identities (pro-school or anti-school, pro-national school or anti-national school).

These divisions, notice, are divisions between adults, or families taken as single whole units; they structured the community on the basis of families or, rather, (usually male) heads of families. But social life was also structured in ways which divided families internally, and aligned the members of local communities across family boundaries and across those lines of division which effectively took families as their basic unit, such as class. And schools were also implicated in maintaining and elaborating these divisions.

Most obviously, schools divided local communities by age: despite the loose practical definitions of the ages of schooling, most schools were institutions for the young, with pupils over the ages of twelve or thirteen years comprising a relatively small proportion of their numbers. Moreover, many schools were directed towards more specific age groups; some took only children under seven, for example, while others, notably advanced schools for the sons or daughters of the middle class, took only older children. Schools, in fact, could be seen as one of the key institutions concerned with constructing finely tuned age relations, segregating different age groups, producing differences in knowledge between them, and defining the relations between different ages in terms of both power and style of personal intercourse. Schooling also divided families and communities by gender. Many mixed schools separated boys from girls in the schoolyard and often in class, while others provided only for one sex. They related sex of pupils to sex of teacher. And they divided communities by gender by restricting school governance to males. Once again, it is important to notice that none of these lines of division nor the ways in which schools were implicated in re/producing them were simple. Many middle-class elementary schools, for instance, provided for girls and young boys under the governance of women teacher proprietors, constructing complex interactions between age, gender, and class divisions.

Schools and their complex relations to social division were deeply implicated in the shaping of local politics. In some places there appears to have been a genuinely united and broad-based local grass-roots action to develop a school. It is possible that here the local movements took the form of a grass-roots participatory democratic politics, at least among the adult men, since women and children were evidently either excluded or marginalized. In others, a broad body of local settlers willingly ceded initiative and control, usually in exchange for support, to a much smaller group of men, to establish, maintain, and manage a school. Here, arguably, we have the formation of a hierarchical, representative form of politics built on the existence or re/construction of a local consensus under the direction of the leading local men. In yet others, particular groups or individuals sought to seize effective control over the local public school, either by pre-empting the initiatives of others in securing a school or by manoeuvring to gain control of a more broadly based movement or existing school. In some 
respects this situation is similar to the previous one, except insofar as there is no apparent hegemonic position.

It is important to notice, too, that where no public funds were involved, the issue was not political at all: support for different schools was a matter of choice within a 'free market.' Divided support became political where the control and use of a public resource was at stake. Even in such cases, open conflict was not always in evidence, at least in the sources available, as some groups for whatever reasons bowed out of the potential conflict to support their own separate, often private, school.

School politics were closely interwoven with the structure and politics of local society more generally. In this context, it is significant that all my examples of what I have suggested might be seen as grass-roots participatory democratic politics come from smaller, relatively unified, and poorer communities. This might, of course, simply reflect inadequately close-grained sources, or insensitive or inadequately theorized analyses of larger, urban localities. In most cases, however, it is relatively easy to identify at least class and religious divisions, and often national identity, as key components in school politics. In addition, whether there was open conflict over the patriarchal governance of school and other aspects of social life or not, the conduct of school matters clearly confirmed and extended the gender politics of local society. Finally, it goes almost without saying that local school politics, in common with virtually all other aspects of colonial social life, excluded Aborigines and Chinese.

Let me indicate some of the dimensions of each with some brief examples. At Camden in New South Wales, the local settlers, organized (or so the surviving official documents indicate) by men of some standing in the community (policeman, clergyman, shopkeepers, and tradesmen) petitioned James and William MacArthur, men of great wealth and standing in the colony whose family estate was centred nearby, to lend their moral, financial, organizational, and political support to the plan to develop a local National school. They agreed, and subsequently dominated the management of the school. ${ }^{27}$ At Sheaoak Log in South Australia, a public meeting convened to establish a school, elect a committee, select a site, and approach the education board for support. However, a group of local landowners, outvoted at the meeting, also approached the board, contesting the meeting's decisions on the grounds that they, as local proprietors, should properly control local affairs, including the location of a school, rather than those who controlled the meeting but who had no 'stake' in the community. ${ }^{28} \mathrm{At}$ Warrnambool on the west coast of Victoria, the local Catholic priest effectively combined his control of church affairs with the power this yielded him within the

27. MacArthur Papers, vol. 84, Mitchell Library, A2982, esp. pp. 3-7.

28. Fawcett to Secretary, Central Board of Education [South Australia], 23 June 1856; Hausell to Secretary, Central Board of Education, 6 Aug. 1856; Fawcett to Secretary, Central Board of Education, 6 Aug. 1856: SAPRO, GRG 18/113/30. 
Catholic community to dominate the affairs of the local state-assisted school. ${ }^{29}$ (His ambitions appear to have been far wider than this; his critics claimed that he styled himself 'the elector of Villiers and Heytesbury,' his parliamentary district.) And finally, at Stirling in the Adelaide hills, smallholders in three distinct parts of the district united behind their 'own' leading local landowners in a struggle to secure the single public school where it would most benefit their own children. Moreover, the struggle for control of the school was conducted in part through the local District Council, tying school politics closer to other local forms of institutionalized power and the social bases on which they drew. ${ }^{30}$

Several things were at stake in these political struggles. Most obviously, perhaps, was the resource of a state-subsidized school, whether for its direct use value for their children, for its symbolic value as a marker of local development, or for its effects on local land values. For parents, the question of the use value of the school was not restricted to physical access (i.e., proximity to home) but included social access (would it be open to their children? or, in other cases, would it be open to 'riff raff' who might lower the tone of the school and contaminate their own children?) and the character (and hence, value) of the education itmight impart. But control of schools could also be seen as part of the more general construction of power in local society. It brought with it such things as the power of being able to investigate into, and sit in judgement over, the lives of neighbours, determining whether they were in need, and worthy, of free places. And, presumably, it brought with it, and symbolized, such intangibles as 'prestige' in the community.

Once more, it is important to note the complexities and uncertainties of local school politics. Local landowners and local priests did not always gain control of their local schools. Consequently, control of schools did not always confirm existing structures of power but, at times, provided a base from which otherwise disenfranchised groups could wield some influence over local affairs. Moreover, even where school politics did confirm other bases of power they provided them with new inflections; 'class,' for instance, was articulated variously as wealth, 'level' of education, interest in education, personal position and following, occupation, 'respectability,' capacity to organize state support, and so on. The role of the state, through the education boards, was important, and double-edged, in this. From the start the education boards and their agents sought to ensure that their schools were under the gaze of men of substance and respectability, which

29. Hurley to Secretary, Board of Education [Victoria], 13 Dec. 1870, VPRS, 892/188.

30. District Council, Crafers, Minutes, 15, 29 Oct., 12, 29 Nov., 10, 22 Dec. 1860, SAPRO, MRG 23/1. Note, too, that this was not uncommon in South Australia; for example, the struggle over the location of the state-supported school in the Woodside-Balhannah-Oakbank area mentioned earlier also played a significant part in, and was shaped by, local District Council politics. 
translates roughly enough as 'middle class." 31 However, they also came to the view that local managers should live close to the schools, a position which often excluded men of any substance and left the school in the hands of workingmen. ${ }^{32}$

\section{Local Society and the State}

Thus far, I have explored the ways in which the processes of providing and running schools shaped local communities as individual communities in themselves. However, they did not exist in themselves, apart from the wider state and society. And, I suggest, the processes of providing and managing local schools were deeply involved in shaping the relations between local communities and the colonial state, even the character and boundaries of 'the state' itself.

Inoted earlier that existing studies establish a significant role for local society in forming the state and state education systems. It forced the elaboration of both the body of regulations and the machinery for implementing them which constituted the institutional form through which the state attempted to shape education. Further, as I have argued elsewhere, the character of local educational activity and its success in adapting state support for local schooling-which actually constituted the failure of the state agencies to secure their aims-interacted with other political conditions to generate pressure for the reconstruction of state provision for and regulation of education in the form of far more highly centralized, bureaucratic systems with considerably expanded briefs and extended powers after 1872 . $^{33}$

This approach identifies the state with 'the machineries of government,' both legislative and executive. In its liberal versions, it positions the state as morally ambiguous: 'good' insofar as it promotes enlightenment and democratic equality in the face of ignorance and inequality, but 'bad' insofar as the power it arrogates to itself fetters freedom and individual initiative. In its revisionist (Marxist and feminist) versions it is more unilaterally 'bad,' in that the power it constructs is directed to the maintenance of a repressive class and gender order; the expansion of the power of the state in the restructuring of state education after 1872 was a

31. Central Board of Education [South Australia], Minutes, 9 Jan. 1856, SAPRO, GRG 50; Board of National Education [New South Wales], Minutes, 5 May 1852, New South Wales State Archives [NSA], 1/331; Board of National Education [Victoria], Minutes, 15, 28 Feb. 1953, VPRS, 876/1; Rusden, Report on proceedings, 31 July, 3 Aug. 1849, NSA, 1/331; Kane, Report on proceedings, 2 Feb. 1853, VPRS, 877.

32. Circular, Board of Education [Victoria] to Inspector-General and Inspectors, 30 June 1866, VPRS, 892/30.

33. Vick, 'Class, Gender and Administration,' and 'School, Community, the State and the Provision of Schools.' 
tactical move to resolve problems in the general strategy of securing a capitalist, patriarchal society.

Curtis's argument, also noted earlier, offers a different view of the state. In this argument the state was educational not only because it supported schools but in that the means by which it supported them involved teaching local communities the proper means of conducting public business-the meaning, in other words, of citizenship in a democratic state and society. Here, whether the objects to which the state (in the sense of the machinery of government) directs its resources are seen as 'good' (the freedom and equality of liberal democracy) or 'bad' (the inequality, exploitation, and repression of patriarchal, capitalist society) the state is seen as constructive-as positive rather than negative. Let me be careful here: I do not mean morally or politically positive (as in 'good'), but as constructing, actively engaged in the process of building society in minute, precise, concrete, localized ways, rather than as simply repressing, holding the lid down on other latent possibilities which were simply waiting to be realized. The processes of state/social formation involved in local/central production of schooling involved teaching local community members 'how things were,' 'how things should be done,' and to accept the propriety of it all. This was not done formally, or through precepts, but through teaching them how to interpret the social, political, and educational practices they saw around them, especially in relation to the school but well beyond it, too.

Again, this is not to say that there were not other possibilities. Indeed, one of the problems in much earlier historiography is that it conjures up a sense of inevitability of developments as they occurred. As Katz argued a quarter-century ago, there were alternatives available. ${ }^{34}$ Curtis's work in Canada, Grundy's account of the possibilities in non-clerical denominationalism in Victoria, my own analyses of educational provision in New South Wales, South Australia, and Victoria more generally during the third quarter of the century, and Theobald's account of the education of 'young ladies' in Victoria a little later, to refer back to just a few studies mentioned earlier, all point in the same direction. However, the positive work of the state actually reconstructed the conditions under which social life was conducted in such a fashion that those possibilities were possibilities no more.

In this context, local central relations were both changing with the form of state, and changing the form of the state. In the 1850s, the establishment of the dual systems (parallel National and Denominational boards) in New South Wales and Victoria and the single, fairly 'minimalist' board in South Australia established forms of colonial state which involved a relatively low level of control of local educational affairs and which were not concentrated in formal bureaus but involved a relatively high level of mobilization of local/citizen agency in administration, production, and support of public schools. The legislation of the 1870 s

34. Katz, Illusion of Educational Change, chap. 1. 
and later created a form of state which imposed far more extensive, intensive, and direct regulation of local public schooling through highly centralized and powerful state bureaus which made local mobilization and engagement at best supplementary, at worst bothersome, and, in any case, generally simply irrelevant.

\section{Conclusion}

I have argued that in the Australian colonies during the third quarter of the nineteenth century the formation and running of schools, especially public schools, played an important and multi-faceted part in the production of local communities. The impact of the school(s) was markedly uneven in both the intensity of its effects and the forms it took from place to place, depending to a large extent on the specific character of local circumstances and conditions, and especially between larger and smaller, or newer, settlements. Whatever the details, however, there were complex interactions between both the conditions and relationships (both local and central) shaping local schooling and the various aspects of social life schooling in turn affected: between the impacts of the school on the development of local geography, social structure, politics, and culture, and between each of these and local geography, the local economy, the national and religious composition of the local community and their institutional expression, the diversity or otherwise of the local population.

I wish to stress the complex, dynamic character of these relations. They direct our attention to the variety of ways (concrete and practical, symbolic, cultural, and conceptual) in which what might be constructed analytically or theoretically as general structural/structuring relations and the means of power they deployed, was apprehended and acted on-lived and naturalized-in daily practices. In particular, they direct attention to the tensions between the formation, of local 'community' identities and the internal structuring of the 'community,' the existence of division and conflict, and the construction of consensus and hegemony.

Crucial to the impact of the school, I suggest, is the construction of public schools and with it, the amplification of the public (political) domain at the local level. This was achieved in part by the marshalling of local private resources, their consolidation in schools, and their constitution as public property-a property which, moreover, functioned as a source of individual as well as community benefits.

Finally, I argue that the particular form that state support for and regulation of schooling took made the local level central to the development of the state and, in fact, incorporated local activity as the state in action. Moreover, in important respects the process of joint central-local activity in providing and managing schools involved teaching local communities the proper forms of active democratic citizenship and public administration. At the same time, as I have argued 
elsewhere, the character of local educational politics constituted a pressure on the central state bureaus which led them to marginalize. Ironically, the very process of teaching local communities how to be active citizens probably helped produce the conditions by which they accepted their own marginalization by the state's central bureaus, their marginalization in if not exclusion from important forms of local state politics, and the direction of their own local public institutional affairs. 